総＼cjkstart説 第56回総会シンポジウム

\title{
顎変形症の標準手術
}

- Le Fort I 型骨切り術一

中嶋正博

\section{Standard surgical technique for jaw deformity \\ - Le Fort I osteotomy -}

\author{
NAKAJIMA Masahiro
}

\begin{abstract}
Othognathic surgery for jaw deformities are most frequently performed in Japan. Regarding those procedures, Le Fort I osteotomy and anterior maxillary alveolar osteotomy in the maxilla, and sagittal split ramus osteotomy, intraoral vertical ramus osteotomy, anterior mandibular alveolar osteotomy, and genioplasty in the mandibule are selected singly or combined based on cases. Among these orthgnathic surgeries, Le Fort I osteotomy is a typical surgical procedure, as well as sagittal split ramus osteotomy. Although the designing of osteotomy lines in Le Fort I osteotomy is simple, this surgical procedure is apt to be regarded as difficult, due to other risk factors in comparison with mandibular osteotomy, such as difficulty in the repositioning of bone segment, complexity of the maxillary bone structure, bleeding, surgical invasion of the nasal cavity and paranasal sinus, and postoperative changes in the nasal base morphology. However, regarding surgical treatment for jaw deformities, Le Fort I osteotomy is considered to be a surgical procedure which we should master, as well as sagittal split ramus osteotomy.

Basically, orthognathic surgeries involve subperiosteal surgical manipulation, and it is simply summarized that Le Fort I osteotomy should also be carefully performed without injuring the periosteum. In order to achieve this, it is necessary to accumulate experience, sufficiently understanding the basic factors to safely perform Le Fort I osteotomy. This manuscript outlines the major points in the surgical procedure of Le Fort I osteotomy.
\end{abstract}

Key words: Le Fort I osteotomy（Le Fort I 型骨切り術），orthognathic surgery（顎矯正手術）, surgical techniqe（手 術手技)

\section{はじめに}

Le Fort I 型骨切り術は 1927 年にWassmund によって はじめて報告され，その後 Obwegeserや Bell らにより改 良され, 現在のように㖽矯正手術の術式として確立され た. 2008 年の日本顎変形症学会のアンケート調査の結果 からわが国では現在, 年間 3,000 件以上の顎矯正手術が行 われているものと推測される ${ }^{1)}$ 。このことから顎矯正手 術は現在に打いては, 一般的な治療法であると思われる. 術式別では下顎枝矢状分割術（SSRO）が最も多く，次い で Le Fort I 型骨切り術，その次に下顎枝垂直骨切り術 (IVRO）が行われている ${ }^{3}$ )。これらは特に顎矯正手術のな

大阪菌科大学口腔外科学第二講座

Second Department of Oral and Maxillofacial Surgery Osaka Dental University
かで基本的な術式であるといえる。本稿では Le Fort I 型 骨切り術の基本術式のポイントについて概説する.

\section{Le Fort I 型骨切り術の適応症}

Le Fort I 型骨切り術は上顎後退症, 中顔面の陥凹を伴 う下顎前突症, 水平的に咬合平面の傾斜を伴う症例, 上顎 骨の左右非対称症例, 垂直的に過成長のみられる症例, 開 咬症などに適応される。しかしながら Le Fort I 型骨切り 術が単独で適応される症例はほとんどなく, 下顎枝矢状分 割術や下顎枝垂直骨切り術などを同時併用する，いわゆる 上下顎同時移動術として行われる。

\section{Le Fort I 型骨切り術のための局所解剖}

Le Fort I 型骨切り術を行ううえで, 神経系では眼窩下神 経, 後上歯槽枝, 鼻口蓋神経, 大口蓋神経が, 血管系では 

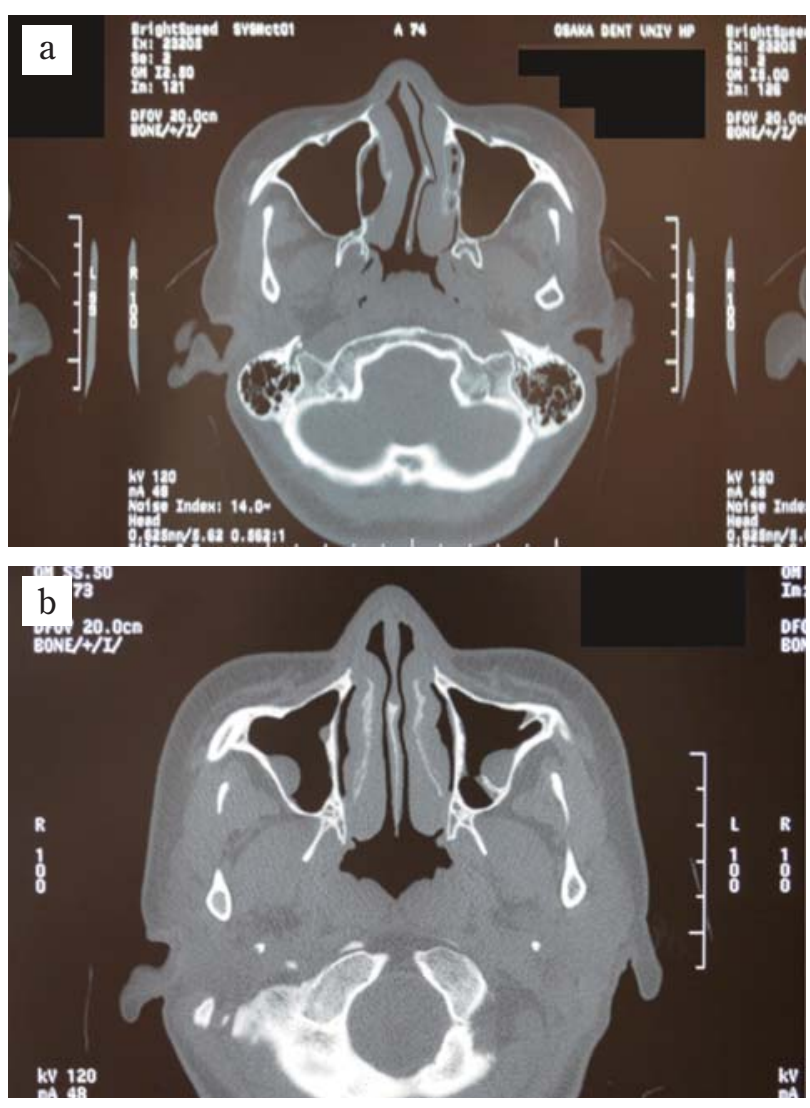

写真 1 術前の CT

骨切り周辺の形態を観察する。
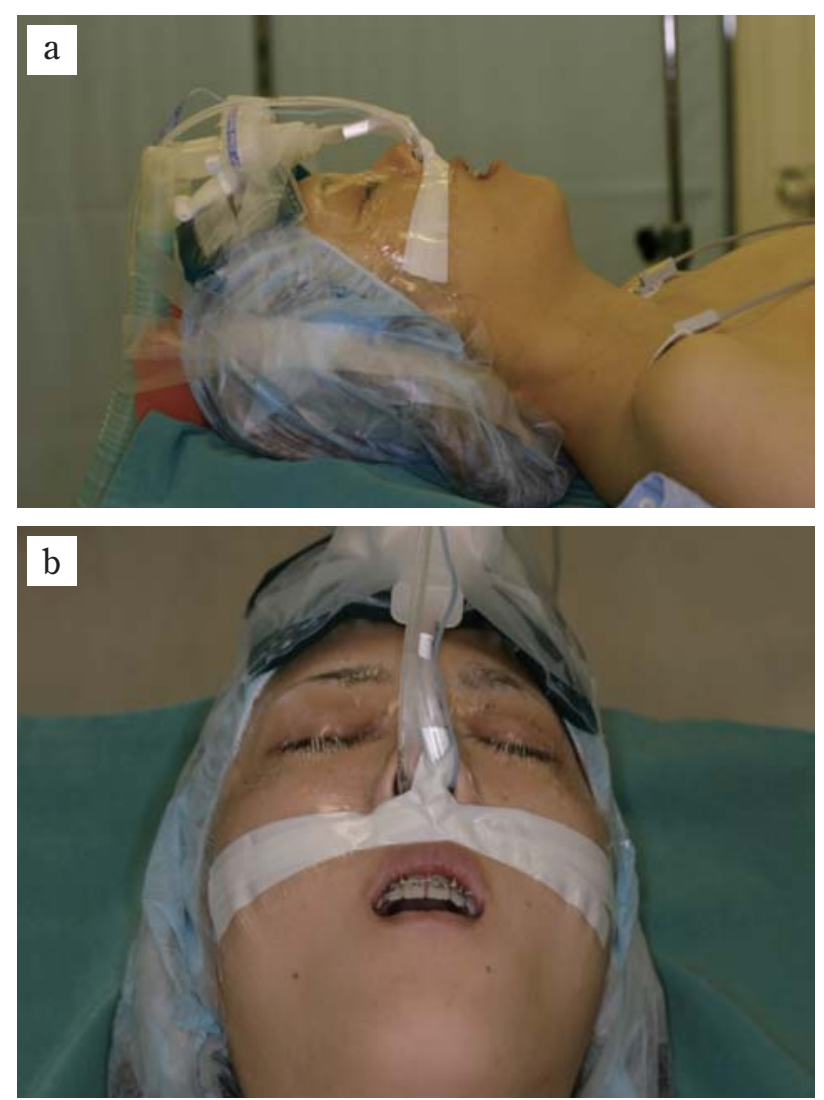

写真 2 手術野の確保と挿管チューブの固定 外鼻形態を変形しないように固定する。

の位置決め用のサージカルスプリントを作成する。また， 輸血のために術前 3 週および 1 週に自己血を各 $400 \mathrm{~mL}$, 計 $800 \mathrm{~mL}$ を準備する。そのほか, 術後に耳管機能の異常 を訴えることが時にみられるため, 耳鼻科に対診し, 鼻腔 粘膜の状態, 鼻腔の大きさ, 鼻中隔の弯曲の有無, 耳管の 機能などの検診を行う.

\section{3. 画像診断}

術前にパノラマエックス線，頭部エックス線規格写真撮 影を行うが，さらに，現在では術前の CT あるいは3D-CT 撮影は必須と考える. CT および 3D-CT は 3 次元的に手術 する部位の把握が可能である。具体的には上顎洞の大き さ, 上顎洞底の位置, 上顎洞粘膜の肥厚の有無, 鼻中隔の 弯曲の有無, 鼻道の大きさ, 鼻腔側壁の骨の厚み, 上顎洞 中隔の有無, 下行口蓋動脈周辺の骨の厚み, 上顎結節部, 翼突上顎縫合部の骨の状態, 梨状口縁から下行口蓋管まで の距離などを確認，検討する（写真 1).

\section{4. 術前準備}

術前準備としてセファロ分析, 模型分析, ペーパーサー ジェリー，モデルサージェリー，画像検査，血液，呼吸機 能検査, 心電眓検査を行う。そしてフェイスボートランス ファーした菊列模型より，モデルサージェリーを行い上顎

\section{5 . Le Fort I 型骨切り術のポイント}

1 ) 頭部の位置と術前準備

麻酔挿管チューブは外鼻形態を変形しないように注意し て固定する。また，上唇や煩部の伸展に影響しないように 挿管チューブを固定する。そして顔面の対称性が確認でき るように眼裂を透明のシールでカバーする（写真 2$)$.

手術に入る前に咬合平面板 (choco-bar) ${ }^{2}$ )を使用して顔 面における基準点間の距離を計測する。特に咬合平面の傾斜 のある非対称症例ではこの方法は非常に有用である (写真 3).

\section{2 ）局所麻酔}

手術に先立ち両側の上顎結節部抢よび骨膜剥離部，大口 蓋孔部扎よび硬口蓋後縁軟組織部に 10 万分の 1 アドレナ リン含有の $1 \%$ リドカインを用いて浸潤麻酔を行う. 

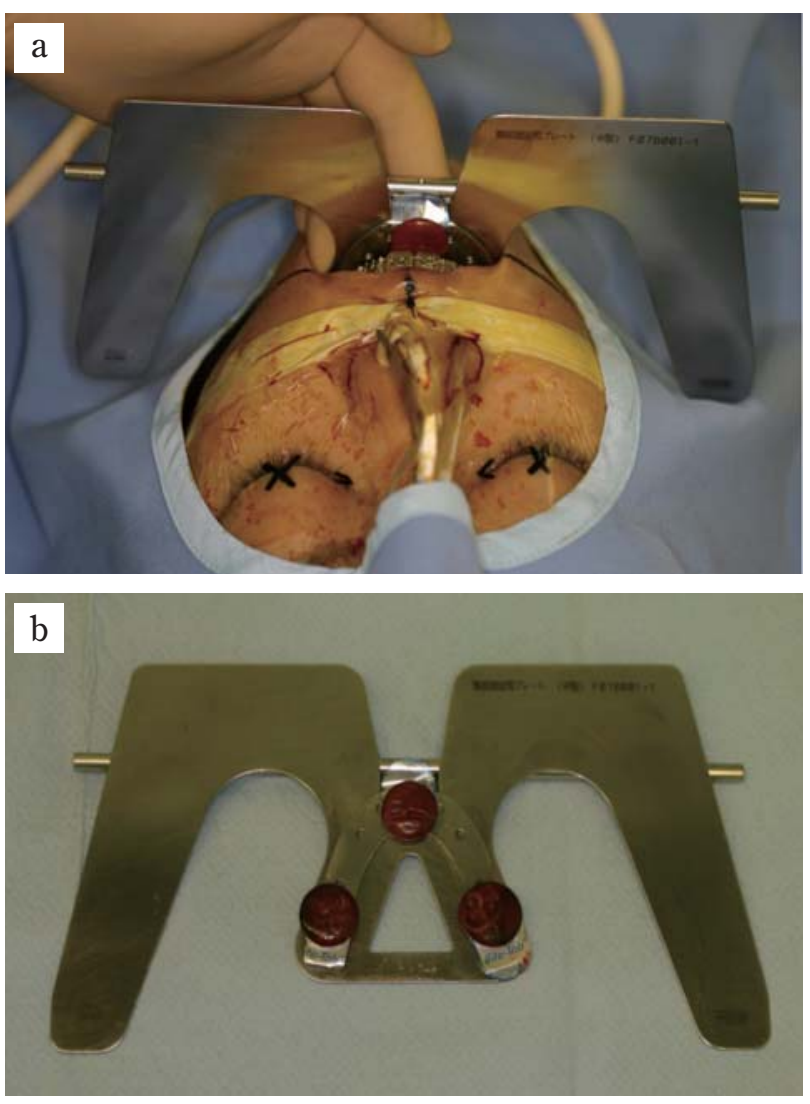

写真 3 咬合平面板の使用

$\mathrm{a}$ ：咬合平面の傾斜の確認 $\quad \mathrm{b}$ ：咬合平面板（choco-bar）

\section{3 ) 粘膜切開}

粘膜切開は口腔前庭部を水平に切開する方法と, 㐘肉溝 に沿った切開を用いる方法 ${ }^{3}$ ) がある（写真 4$)$ 。われわれ は両犬菌間に茵肉溝に沿う切開を行い, 犬菌部で縦切開を 加え, 第 1 大臼柬近心部まで歯肉煩移行部に切開を行う方 法を行っている. 㐘肉溝に沿う切開の利点としては (1)前茵 部の柬肉唇移行部に手術の痒痕が残らず違和感が少なく柬 肉の感覚の消失がないこと, (2)鼻・口唇の筋肉を切離しな いため, 鼻翼の変形が少ないことが挙げられる。一方, 欠 点としては術後に辺縁柬肉の瘢痕拘縮による退縮が生じる 可能性があり, 成人で柬周病が著しい症例や菌冠修復がな されている症例には注意が必要となる。

口腔前庭部の粘膜切開は柬肉煩移行部やや上方に設定す る. 初めは粘膜面に対してメスの角度を直角に操作し, 次 いで粘膜が切離されれば，骨面に直角になるようにメスの 角度を変え骨膜を切離する。大臼菌部では煩筋を切離する と煩脂肪体の脱出が起こるため, 粘膜切開は第 1 大臼柬近 心までに止めるようにする，柬間乳頭部の切離は柬間乳頭 部が挫滅創にならないように，確実に菌周勒帯まで鋭的に 切離する。
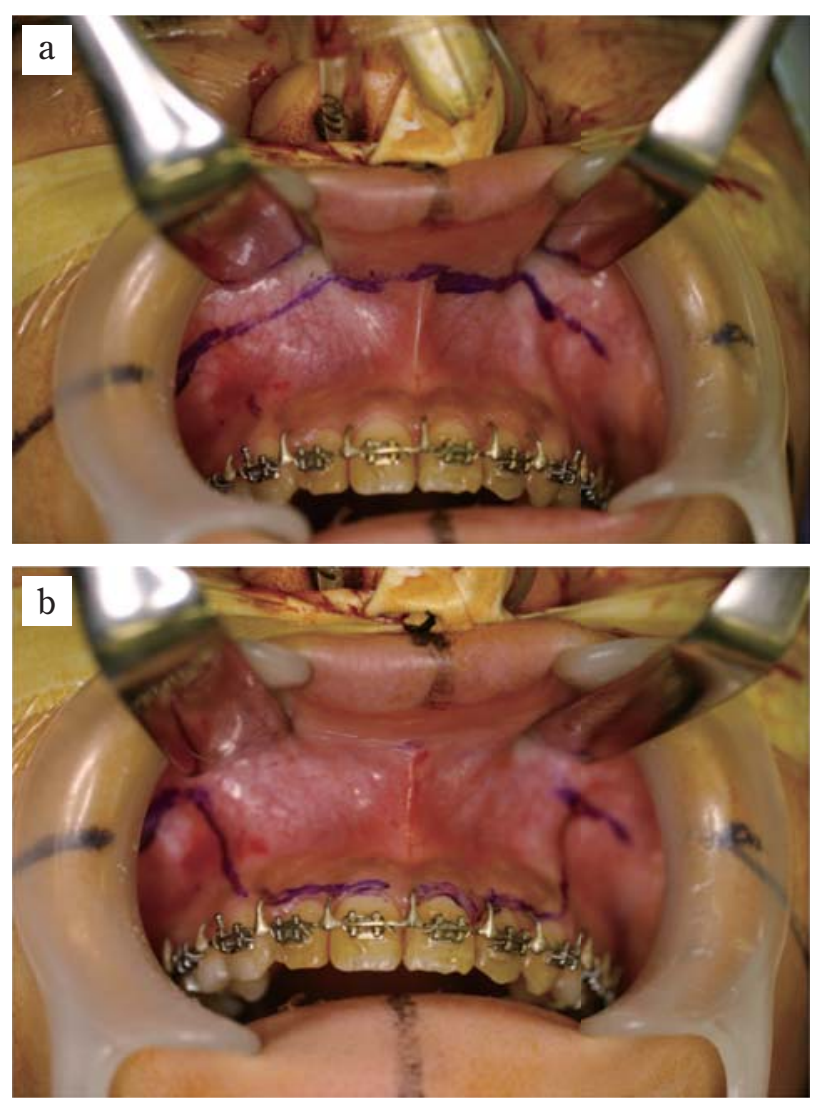

写真 4 粘膜切開線

$\mathrm{a}$ ：口腔前庭切開 $\mathrm{b}$ : 㐘肉溝に沿う切開

\section{4 ) 粘膜剥離}

粘膜の剥離は蒾頸部の剥離から始めるが, 㐘頸部から根 尖側に剥離を行うのではなく, 辺縁歯肉の剥離を行った後, 犬茵部の縦切開部より近心側に向かって, 骨に付着してい る筋組織を骨より削ぐような要領で剥離操作を行う。この 部分での骨膜の損傷，挫滅は術後の内出血の原因になるた め, 丁寧に剥離操作を行う。鼻腔底部の剥離は茵科用の剥 離子で梨状口縁を明示した後, 先の弯曲した耳鼻科用の剥 離子を用いて鼻腔底粘膜を丁寧に剥離する。鼻腔底部は梨 状口縁よりやや下方のため, 鼻腔底の形態を考えて, 盲目 的操作になるが，剥離子の先端が常に骨に触れていること を意識しながら操作することが肝要である， 口蓋骨の後縁 に達すれば，骨の抵抗感がなくなった感触が手に伝わって くる，この感覚を覚えておくことがポイントである，鼻腔 底部の剥離は鼻中隔の切離の際に鼻腔粘膜を損傷しないよ うに確実かつできるだけ広く行い, 鼻中隔および鼻腔側壁 へも剥離を広げて打く，特に挿管側は剥離操作に余裕がな いため粘膜を損傷しないように注意する必要がある。剥離 が終了すれば止血のためにボスミンを浸したタンポンガー ゼを挿入しておく。

上顎洞前壁の剥離は容易であるが，プレート固定部を 


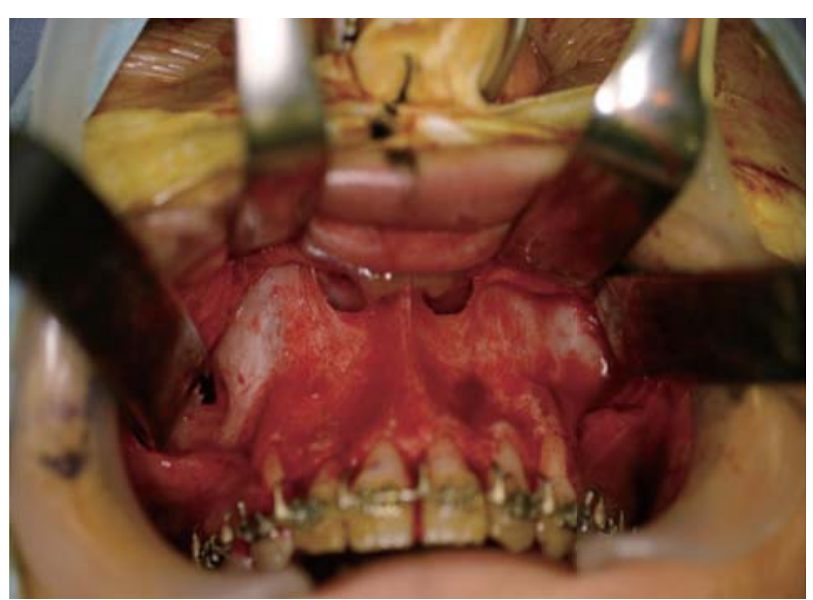

写真 5 粘膜剥離

骨切り予定線よりやや広めに剥離する。
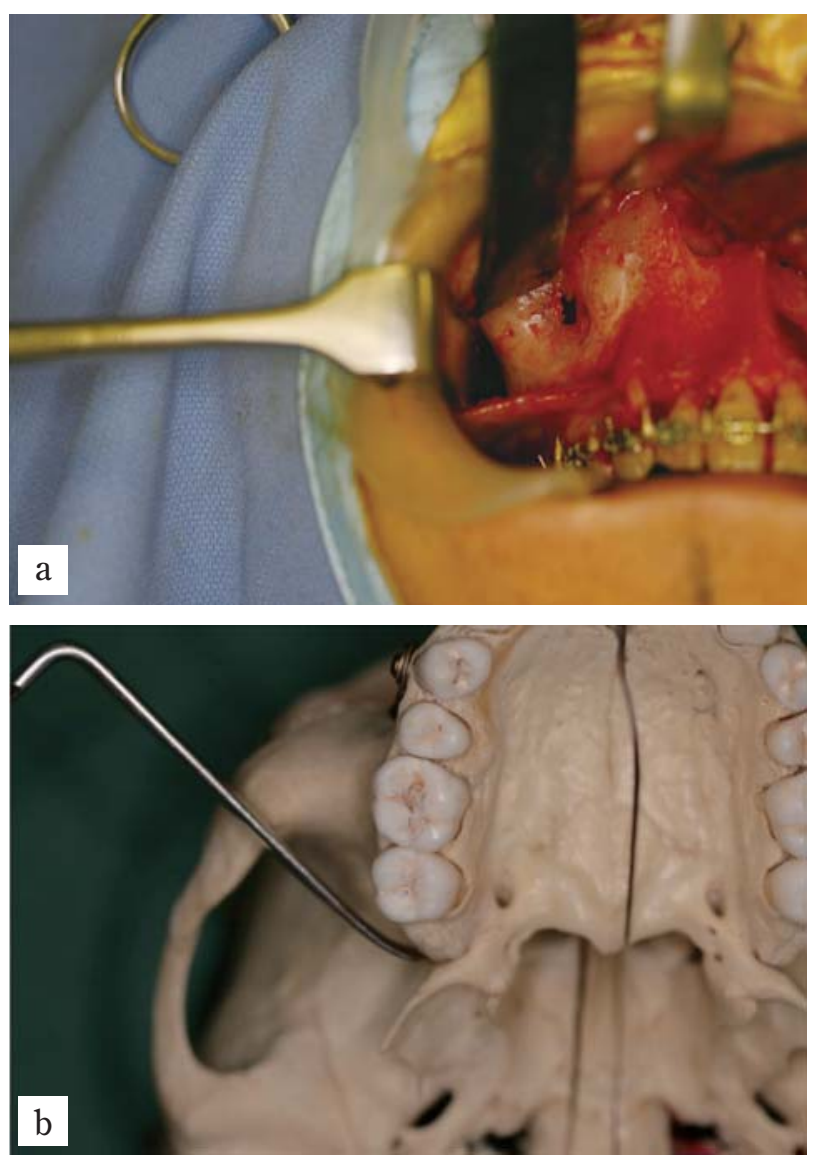

写真 6 翼突上顎縫合部の剥離, 上曲がり鈎の装入 上曲り鈎を翼突上顎縫合部に確実に装入する。

想定して, 骨切り予定線よりやや広めに剥離する（写真 5)。剥離操作を遠心に進め，上顎骨煩骨突起の基部を確認 したのち, 上靧結節部の剥離を行い, 翼突上靧縫合部を確 認する. 先が少しカーブになった耳鼻科用粘膜剥離子やフ リューエル剥離子を用いると便利である。骨膜下でトンネ

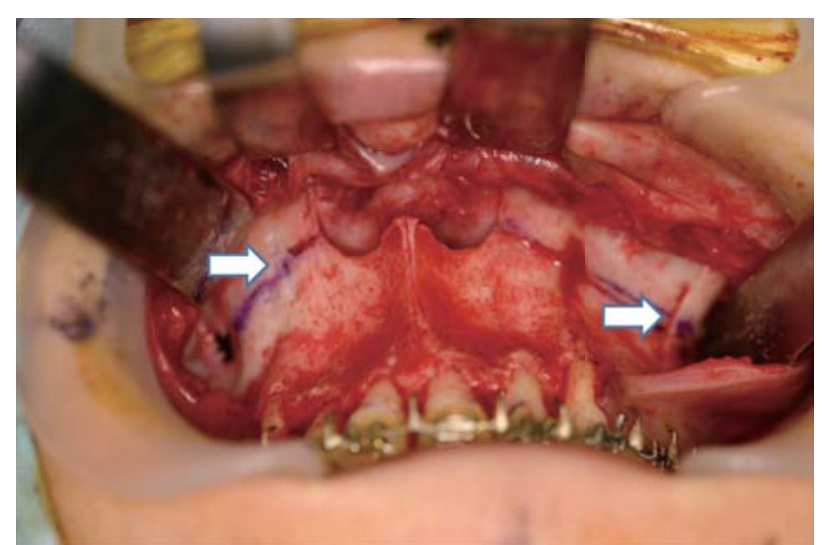

写真 7 骨切り線の印記, リファレンスマークの付与 (矢印)
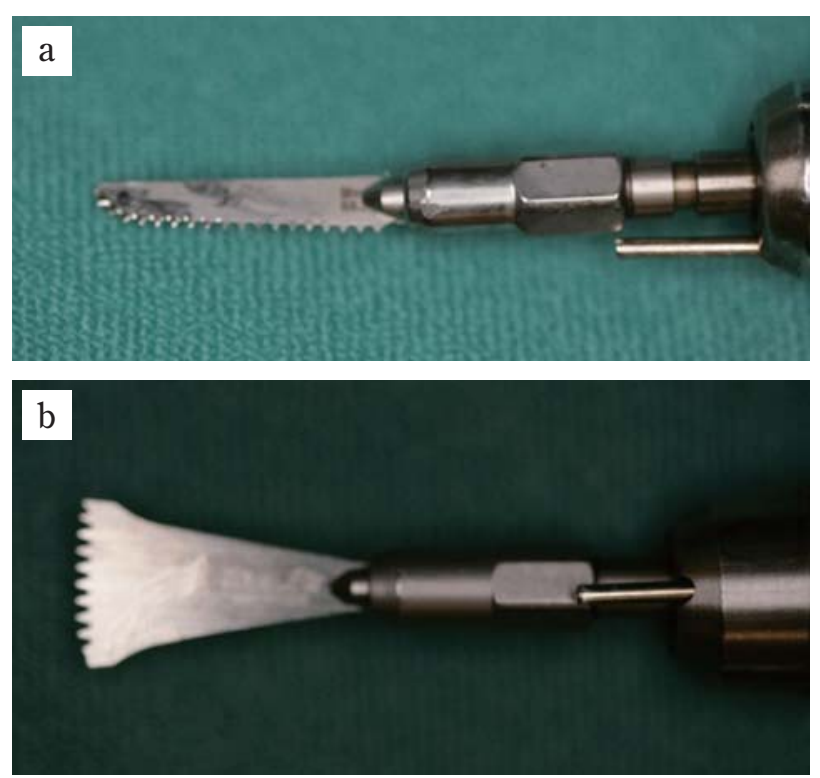

写真 8 レシプロケーティングソー $(\mathrm{a}$ ), サジタルソー ( b )

ル状の操作となるため, 盲目的になるが剥離子の先端で確 実に翼突上顎縫合部を確認する。この部では特に骨膜下の 操作を意識して，骨膜を損傷しないようにする，骨膜損傷 は上方では翼突筋静脈叢損傷による出血, 下方では煩脂肪 体の脱出による手術操作の妨げが生じる．翼突上䫴縫合部 が確認できればその部分に上曲りのリトラクターを装入し， 創部を展開する (写真 6)。午の後, ボスミンを浸したタン ポンガーゼを挿入して打く.

\section{5 ) 骨切り線の印記と骨切り}

歯根尖より $5 \mathrm{~mm}$ 離れた骨上に骨切りの予定線を印記す る。予定骨切り線上に交わるリファレンスマークをフッ シャーバーにて印記して打き, 移動後の目安とする（写真 7)。サジタルソーとレシプロケーティングソー (写真 8$)$ 

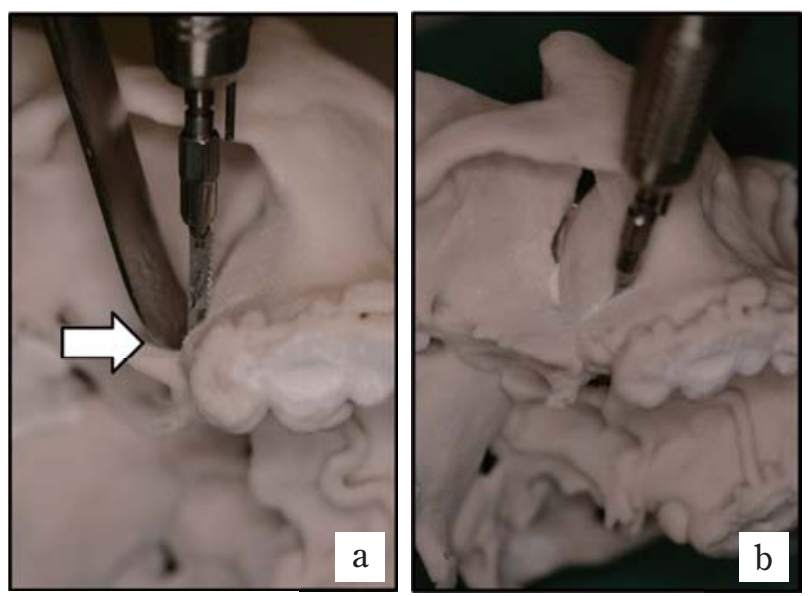

写真 9 レシプロケーティングソーによる上嶺骨後方の骨切り 上曲がり銁を翼突上顎縫合部に確実に装入し，軟組織の 損傷を防止する (矢印).

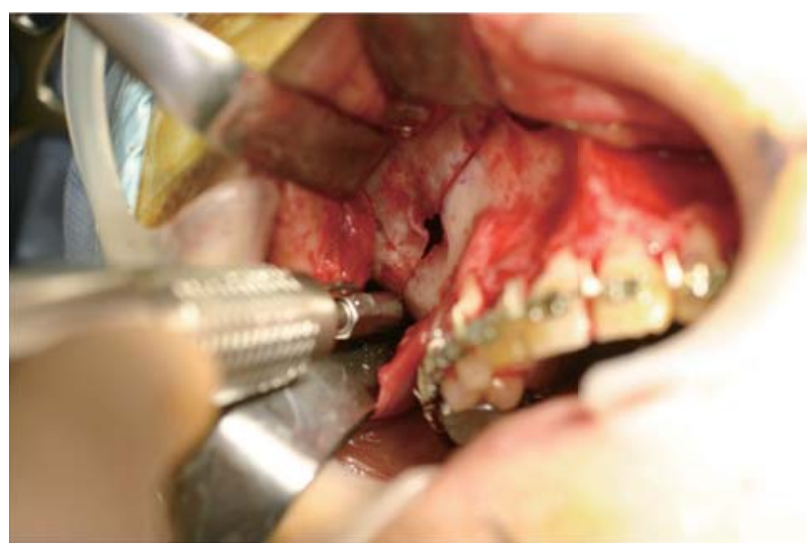

写真 10 レシプロケーティングソーによる 上顎骨後方の骨切り

翼突上顎縫合部を上曲りのリトラクターで確実に保護 しながら骨切りを行う。

を用いて梨状口縁から，鼻腔側壁，上顎洞前壁，上顎結節 部，翼突上顎縫合部まで骨切りを行う。上顎骨後方部の骨 切りは使用する器具の長さを把握しておき, 深部まで切離 しないように注意する。また，翼突上㴿縫合部を上曲りの リトラクターで確実に保護し, 切削器具による軟組織の損 傷を防止する（写真 9, 10）。

鼻腔側壁部の骨切りでは鼻腔粘膜の保護のために鼻腔側 に剥離子を挿入し，骨切りを行う。鼻腔側壁の後方は術前 の CT で梨状口縁から下行口蓋管までの距離を計測してお き，下行口蓋動脈を損傷しないように薄刃のノミで鼻腔側 壁を切離する，日本人の場合約 $30 \mathrm{~mm}$ を目安とする報告が ある ${ }^{4)}$. 最後に後鼻孔部に口腔側よりガーゼパックを挿入 し，指で保護しながら，鼻中隔マイセルにて鼻中隔を切離

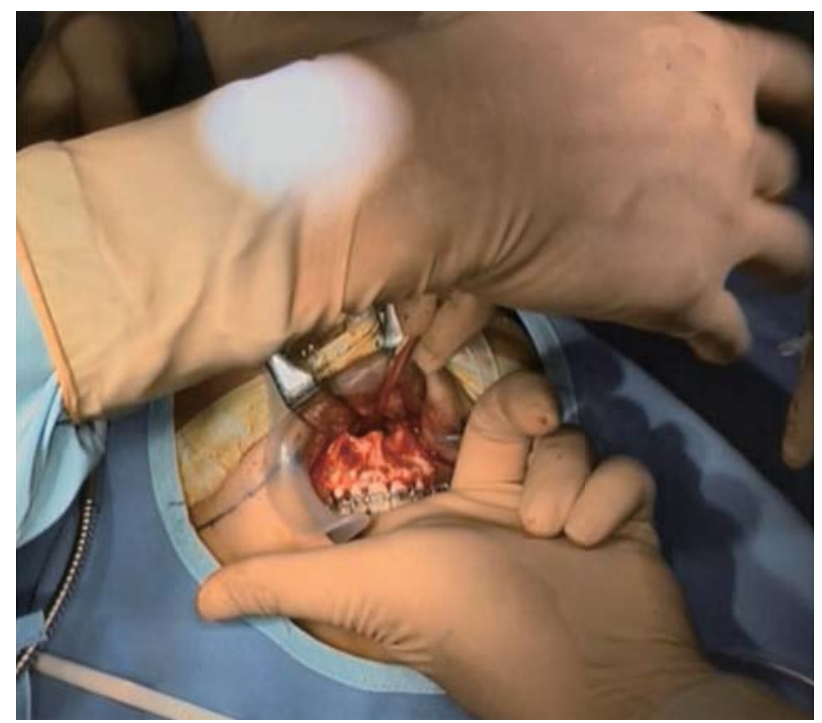

写真 11 鼻中隔の切離

後鼻孔部を指で保護しながら, 鼻中隔マイセルにて切 離を行う。

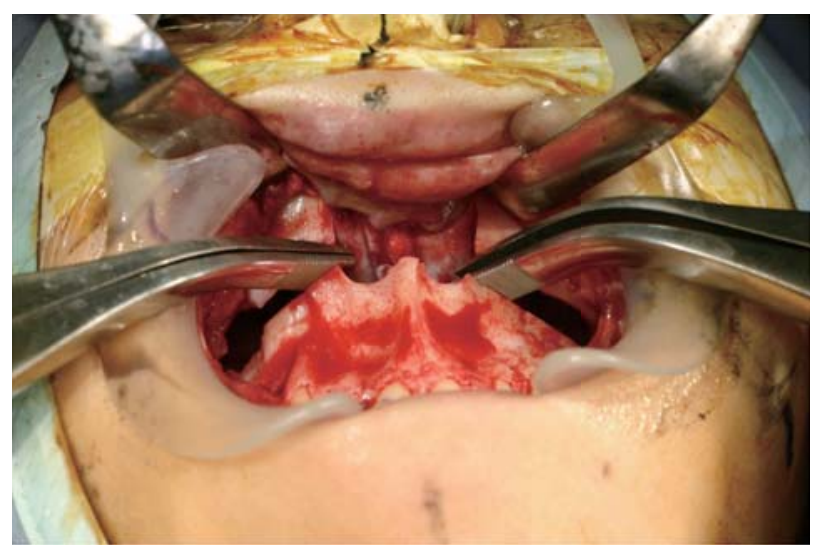

写真 12 ダウンフラクチャー

セパレーターを両側の梨状口縁部に装着

する. 鼻中隔の切離はほとんどの場合, 手掌による桘打で 切離が可能である (写真 11).

6 ) ダウンフラクチャー

骨切りが終了すれば，翼突上顎縫合部の分離を行う。縫 合部の分離は通常はプテリゴイドオステオトームを用いて 行うが，プテリゴイドオステオトーム使用時の出血のリス クを避けるために，われわれはオステオトームを用いない 方法で行っている ${ }^{5,6)}$. まず, 梨状口縁の骨切り部に骨, ミを挿入し，こじるようにして反対側の梨状口縁部にボー ンセパレーターを挿入し，ゆっくりと力を入れながら骨切 り部を開大させ，両側にセパレーターを挿入する（写真 12)，骨の抵抗感を手で感じながらセパレーターを操作す る.この際の手の感覚が重要で, 抵抗が強い場合には, 再 


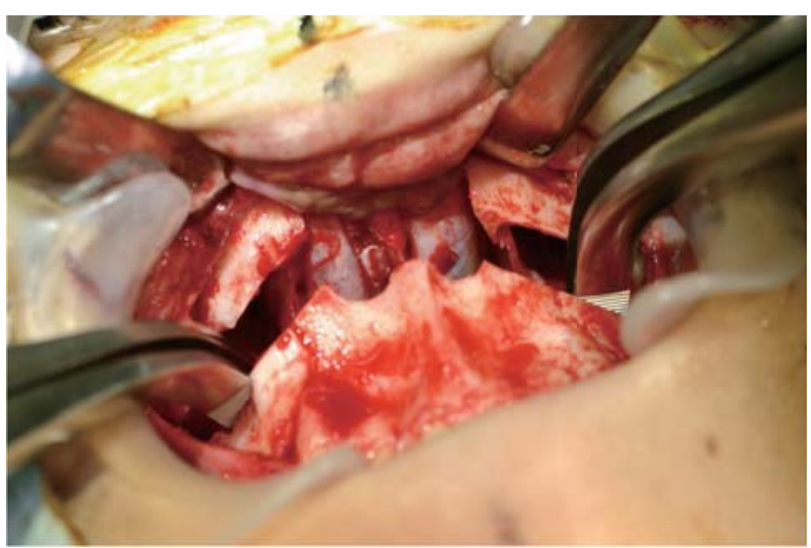

写真 13 ダウンフラクチャー セパレーターを煩骨柬槽稜部に装着

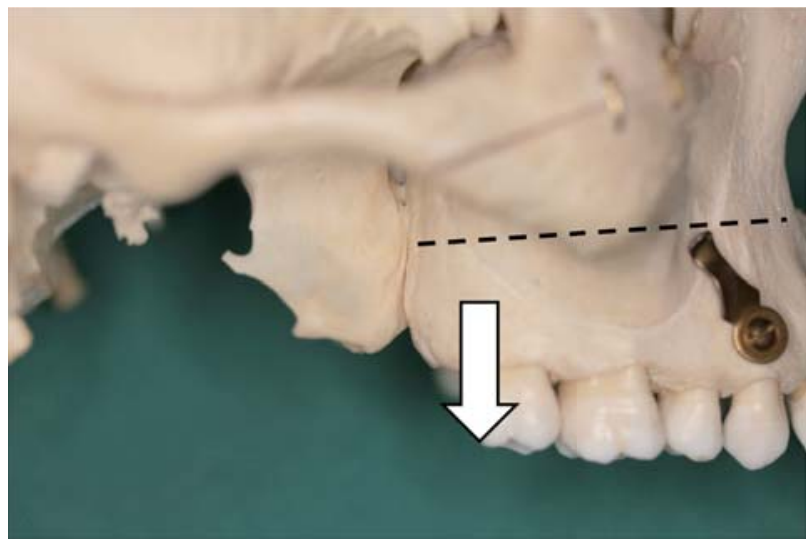

写真 14 セパレーターの力の方向 (矢印) 矢印の方向に上䫏結節部を下方に押し下げるように操 作する .

度骨切り状態を確認する。次に, 煩骨下稜部にセパレータ 一を移動させ左右同じ力でダウンフラクチャーをさせる (写真 13)。その際のセパレーターの力の方向は上顎結節 部を下方に押し下げるように, 左右同じ力でセパレーター を操作することがコッである (写真 14). ダウンフラク チャー後, 硬口蓋後縁に付着している軟組織を剥離し, 骨 片の可動性が十分に得られたかを確認する.

\section{7 ）上顎骨の位置決め}

位置決め用のスプリントを装着し，下顎を開閉口させな がら, 骨の干渉部を確認し, トリミングを行う。下行口蓋 動脈周辺では回転切削器具は使用できないため, 耳鼻科用 破骨鉗子（写真 15）を用いて，骨を破砕するようようにし ながら少しずつ骨を除去する。

\section{8 ）骨片の固定・縫合}

骨片の固定は梨状口縁部, 煩骨下稜部に上顎用のチタン ミニプレートあるいは吸収性プレートにて左右 4 か所で固
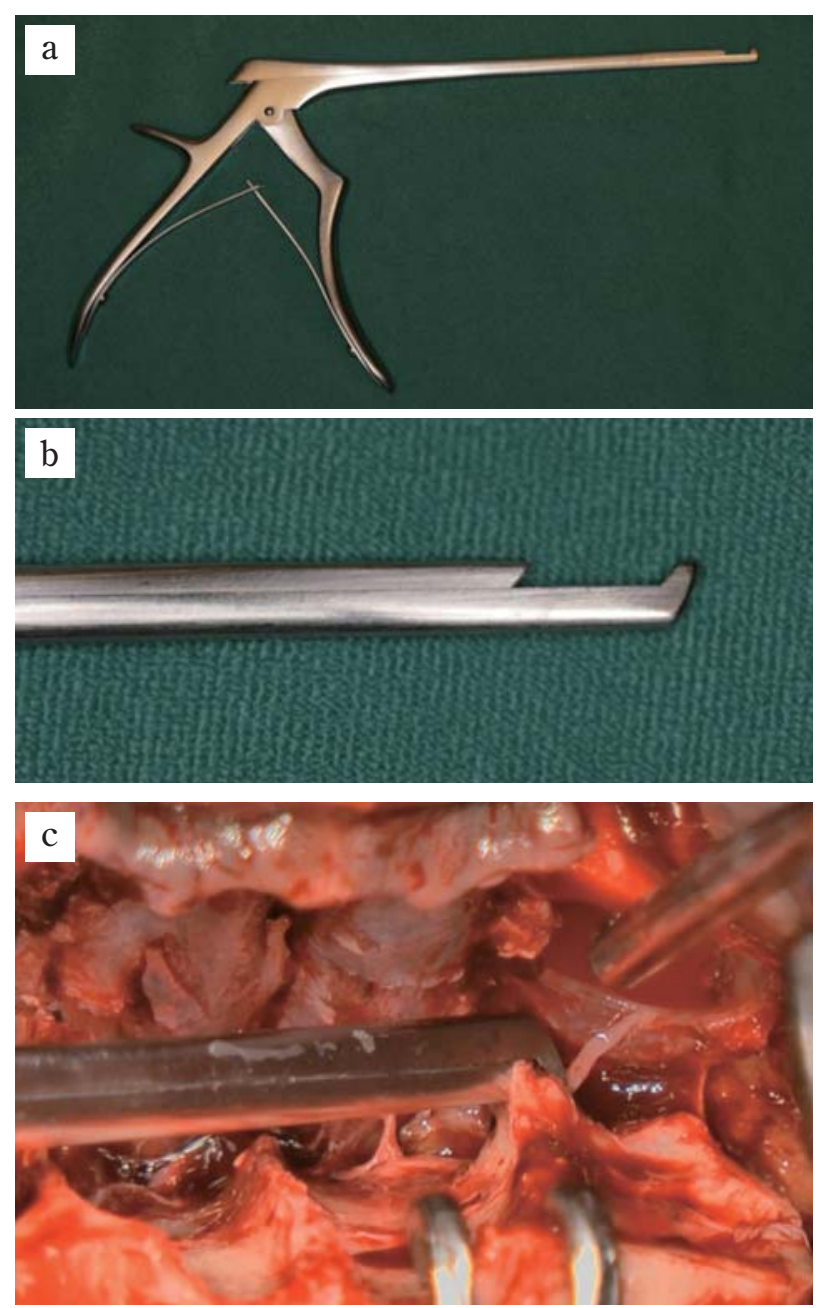

写真 15 耳鼻科用破骨鉏子の使用 $(\mathrm{a}, \mathrm{b})$, 下行口蓋動脈周辺のトリミング（ $\mathrm{c}$ )

定する（写真 16）.

9 ) 縫合・Alar base cinch suture

口腔前庭切開の場合は鼻筋, 口唇の筋肉が切離されるた め, 鼻翼の広がりを防止するために Alar base cinch suture が必要である ${ }^{7)}$. しかし前柬部で㐘肉縁に沿う切開を行っ た場合には筋の切離がないため, 鼻翼の広がりは少なく, 鼻翼の基部を 4 - 0 バイクリル糸で軽く寄せるように縫合 し, 拡大を防止する。また, 前方移動量が大きい症例では 前鼻棘に骨孔を穿ち, 骨孔と鼻中隔軟骨を軽く縫合し, 鼻 尖部の上向きを防止する。

臼歯部はバイクリル系で骨膜を縫合し, 次に粘膜縫合を 行う。前㐘部の柬頸部の縫合は歯頸部の露出が生じないよ うに丁寧に粘膜弁を復位させ縫合する。

\section{6. 周術期の管理}

Le Fort I 型骨切り術の周術期管理で最も重要なことは 

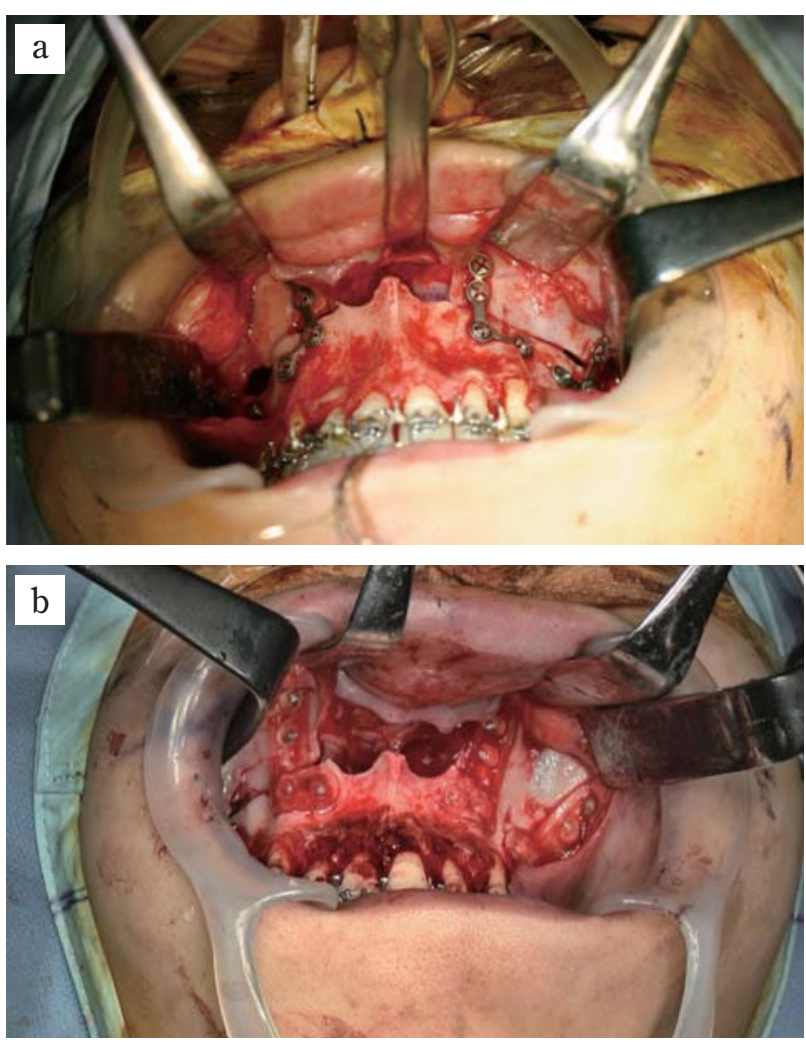

写真 16 骨接合

$\mathrm{a}$ ：チタンミニプレート b：吸収性プレート

術直後の呼吸管理である，気道に影響するものとしては咽 頭部抢よび鼻腔内の浮腫・腫脹, 口腔内および鼻腔内の出 血, 分泌物である. 術後は必要に応じてパルスオキシメー ターを使用して，モニタニングを行い，術直後は頻回に鼻 腔内の吸引を行い, 出血に対して注意深く観察を行う. 数 日後の出血症例も報告されているため ${ }^{8)}$, 術後から数日間 は出血の有無と呼吸状態の管理を十分に行う必要がある. 鼻腔からの出血に対しては鼻腔タンポンの挿入を行う。ま た術直後鼻腔粘膜の浮腫による鼻閉が認められる場合には 血管収縮薬を用いて, エアウエイの拥入を行い, 気道を確 保する. Le Fort I 型骨切り術の場合ほとんどが下䫟の手 術も同時に施行されているため，下㠝枝内側，咽頭部の浮 腫・腫脹の状態も確認する. 術後腫脹の対策にはステロイ ドを 3 日間（デカドロン注射液 $3.3 \mathrm{mg}^{\circledR}$ : 術中, 術後に $9.9 \mathrm{mg} /$ 分 3 , 術後 1,2 日に $6.6 \mathrm{mg} /$ 分 2) 投与する. また, 鼻腔粘膜の浮腫対応として点鼻薬の使用を行う。術後の嘔 気, 嘔吐も周術期管理上重要な問題点である ${ }^{9)}$, 術後の嘔 吐は気道閉塞のリスクや誤嚥による肺炎の原因となる。嘔 気・嘔吐対策として制吐剤や $\mathrm{H} 2$ ブロッカーを使用する. また, 血液の嚥下は嘔気, 嘔吐の誘因となるため術後の出 血の管理と吸引は重要である。ささらに感染予防として抗菌 薬の静脈内投与を 3 日間行う。手術当日の靧間固定は避け,
翌日に顎間ゴムを用い, $2 \sim 3$ 日後, 呼吸状態, 浮腫・腫 脹の状態, 咬合状態を確認した後に, 必要に応じてワイヤ 一による顎間固定を行う。

\section{まと め}

Le Fort I 型骨切り術に限らす䫇矯正手術は基本的に骨 膜下の手術であり, 骨膜を損傷しないように丁寧に行うこ とがまず基本で, 明視下で行うこと, 神経, 血管を損傷し ないことに尽きるといっても過言ではない。午のためには 局所の手術解剖を理解し, 術中の出血を最小限に手術を行 うように努めることを再度強調したい。他の顎变形症手術 を習熟するためにも下顎枝矢状分割術と Le Fort I 型骨切 り術は顎変形症手術の基本術式であり，手術に対する知識 と技術の経験を積み，習得しなければならない。

謝辞

本論文の内容は 2011 年 10 月 23 日第 56 回日本口腔外科学会 総会・学術大会シンポジゥム 3 「䫇变形症の標準手術」の内 容に加筆した。このような総説執筆の機会を与えて頂きまし た関係各位に感謝申し上げます。

\section{引用文献}

1) 小林正治, 斎藤 力, 他: 本邦に打ける買変形症治 療の実態調査. 日顎変形誌 18: 237-250, 2008.

2) 鶴木 隆, 鶴木太郎他: 全上下顎同時移動術にお いて, 術中骨切り骨片の位置策定に用いる鶴木式 choco-barの紹介．日顎変形誌 16: 84, 2006.

3 ) 高木多加志：出血を抑えた Le Fort I 型骨切り術の コッ, 口腔外科ハンドマニュアル, 08 , 口腔外科学 会編. クインテッセンス出版, 東京, 2010, 241-254頁.

4 ）河原日登美, 大村 進, 他：Le Fort I 型骨切り術 のための CTによる下行口蓋動脈の走行位置の解剖 学的検討. 日顎変形誌 14: 18-25, 2004.

5 ) Precious DS, Morrison A, et al : Pterigomaxillary Separation Without the Use an Osteotome. J Oral Maxillofac Surg 49: 98-99, 1991.

6) 斎藤 力, 小林正治：Le Fort I 型骨切り術, 口腔 外科ハンドマニュアル, 06, 口腔外科学会編. クイン テッセンス出版, 東京, 2008, 57-65 頁.

7 ) Stewart A and Edler RJ : Efficacy and Stability of the alar base cinch suture. Br J Oral and Maxillofac Surg 49: 623-626, 2011.

8 ) Dennis TL, Juliana HH, et al : Major Vascular Complications of Orthognathc Surgery : Hemorrhage Associated With Le Fort I Osteotomies. J Oral Maxillofac Sug 48: 561-573, 1990.

9 ) 大井一浩, 井上農夫男, 他 : 顎変形症患者の術後の 嘔気・嘔吐に関する検討. 日顎変形誌 20: 1-7, 2010. 